\title{
Flood defense in Bekasi City, Indonesia
}

\author{
T. Kadri \\ Department of Civil Engineering, Trisakti University Jakarta, Indonesia
}

\begin{abstract}
Bekasi is a development city near Jakarta and is the capital city of Indonesia. The total population of Bekasi has reached 1.8 million (2003) with a population density of about 8.595 people per square kilometer and an area of about 21.049 ha. The growing population and business activities have caused a tremendous conversion of agricultural land for houses, offices industrial parks, etc. This changing land use is increasing the run-off coefficient, which in turn is causing floods in the rainy seasons.

To manage and reduce the flood risks, planners and decision makers are in need of accurate information on the spatial distribution, magnitude and depth of flooding, and on the land use affected by it. Integration between hydrologic modeling and a Geographic Information System (GIS) has exhibited advantages for flood defense. This technology allows storage of the information and improves information accessibility. In terms of flood defense, GIS provides a contribution for data display, storage and retrieval, site selection, impact assessment, and modeling.
\end{abstract}

Keywords: GIS modeling, hydrological modeling, flood defense.

\section{Introduction}

Over recent years, Bekasi Town has been overwhelmed by floods that cause billions of rupiah of damage in financial terms, as well as material losses to the people who live along the river bank of the Bekasi Hulu River. The first flood catastrophe happened in the year 2002, then the same occurred in the year 2005 and then again in the first quarter of 2007.

The floods in Bekasi are getting bigger, with rainfall of $250 \mathrm{~mm}$ in 2002 that caused a river discharge in the Bekasi dam of $578.6 \mathrm{~m}^{3} / \mathrm{s}$. Even with less rainfall, about $127 \mathrm{~mm}$ in 2005 , the river discharge of $545 \mathrm{~m}^{3} / \mathrm{s}$ almost reached the 2002 
level. This shows a bigger discharge of water flow even though the rain was less, so the problem of water flow in Bekasi must be seriously addressed.

One cause of the larger overflow is the growth of population in Bekasi, which is high and grew by $6.3 \%$ in 1980-2002. In 2003 the total population in Bekasi reached $1,809,306$ people, with a population density that reached $8.596 / \mathrm{km}^{2}$ according to the Statistic Central Bureau [5].

The floods were due to the degenerating condition of the watershed in the Bekasi Hulu, which is indicated by the river's daily maximum discharge escalation against the river's minimum water discharge. On the other hand, the flow capacity of the Bekasi Hulu River is insufficient to flow the excessive water from upstream.

The growing population and business activities have caused a tremendous conversion of agricultural land for houses, shopping centers, schools, offices industrial parks, parking areas, highways, and airports. This changing land use is likely to become the source of much erosion/sediment, runoff and garbage that fills and pollutes rivers, drainage channels and reservoirs (ponds, lakes) which in turn cause floods in the rainy seasons. On the other hand, the changing land use is the main cause of decreasing infiltration and ground water table changes that in turn are causing drought in dry seasons.

Based on the population growth, the change in land use is significant. This problem has caused the land use of the Bekasi River area (39,045 ha) to change quickly. In five years (1998-2003) the land use change for forest was $4.58 \%$ and plantation $11.39 \%$, while the growth in housing was $13.90 \%$, scrub land $4.87 \%$ and non-vegetations land $5.09 \%$. The growth in housing is the biggest change.

The rate of runoff in rainy seasons is increasing due to the decrease of the infiltration rate. The run-off coefficient increased from 0.46 in 1998 to 0.62 in 2003. The increasing runoff coefficient has caused floods more frequently with higher intensity and broader damaged areas. Floods in 2002 inundated 12 locations in Bekasi, which covered 164.5 ha, the depth of water logged ranged from $0.2 \mathrm{~m}$ to $3.0 \mathrm{~m}$ and length of inundation ranged from two hours to 10 days.

\section{Hydrology analysis}

The purpose of the hydrology analysis on the Bekasi watershed is:

a. to establish the hydrology characteristic,

b. to analyze the influence of the land use changes,

c. to formulate basic recommendations to reduce the flood risk.

These analyses use a hydrology model that is combined with a spatial geographical information system. The hydrology model analyzes the rainfall pattern and the hydrology response of the watershed by a simulation model. Hydrology analysis on this research use the HEC-HMS program V 2.11 (Hydrologic Engineering Center-Hydrologic Modeling System).

This program consists of three model components, the basin model, the meteorology model and specification control by Pistocchi and Mazzoli [4]. The basic data needed to run the model uses the DEM (digital elevation model), digital data (DXF format) 1:25000 and rainfall data for the years 1974-2002 from the Statistic Central Bureau [5]. 
$6^{\circ} \mathrm{LS}$

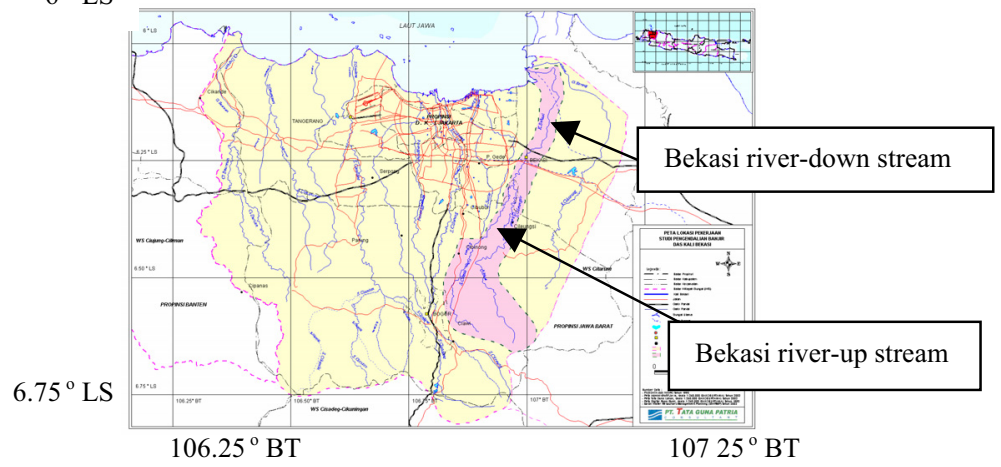

Figure 1: $\quad$ Location of the study.

Rain characteristics based on eight rainfall stations over 28 years (19742002), show the biggest maximum daily rainfall of $250 \mathrm{~mm}$ noted in Bekasi Station on 30 January 2002, and the smallest maximum daily rainfall of $133 \mathrm{~mm}$ in Gunung Putri station on 8 September 2001 (Statistic Central Bureau [5]).

The characteristic mean flow of the Bekasi River based on 15 years of data (1991-2005) is shown in figure 2. The figure shows that the mean inflow minimum monthly and maximum happens in February and September respectively. The biggest flow happened in February at $104.3 \mathrm{~m}^{3} / \mathrm{s}$ and smallest in September with $4.5 \mathrm{~m}^{3} / \mathrm{s}$. The biggest recorded flow happened on 1st February 2002 with $578.6 \mathrm{~m}^{3} / \mathrm{s}$.

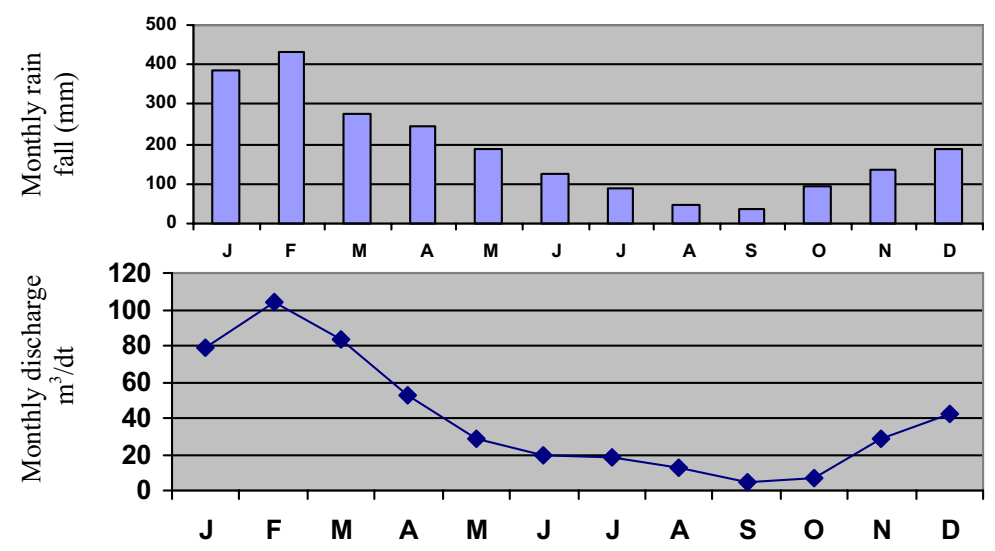

Figure 2: $\quad$ Mean rain and flow of Bekasi River.

\section{Analysis of the influence of land use change}

The analysis is based on a 1: 25000 digital map from Bakosurtanal, which was interpreted by Forest Faculty IPB [2]. The water volume analysis use hydrology 
model HEC-HMS v 2.2.1, which is completed by HEC-geo HMS as the interface with the geographic information system using Arc View v.3.2. This analysis is to find the influence of land use changes in 1998 and 2003.

The land use has changed through significant conversion of its utilizisation, compared to the year 1998, within five years the land use decreased as follows: water $0.82 \%$, forest $4.58 \%$, plantation $11.39 \%$, irrigation $2.11 \%$, semi-title land $3.25 \%$, farm $1.72 \%$. The decrease in land used for water sourcing is parallel to the increase in land used for housing $13.90 \%$, shrubland $4.87 \%$ and nonvegetation land $5.09 \%$.

Table 1: $\quad$ The land use of Bekasi River (1998-2003).

\begin{tabular}{lccc}
\hline & \multicolumn{3}{c}{ Land use (Ha) } \\
\cline { 2 - 4 } \multicolumn{1}{c}{ Land use } & 1998 & 2003 & $\begin{array}{c}\text { Change of } \\
\text { Land Use } \\
(\%)\end{array}$ \\
\hline Water & 764.4 & 443.8 & -0.82 \\
Forest & 4.052 .3 & $2,264.4$ & -4.58 \\
Housing & $1,715.2$ & $7,142.9$ & 13.90 \\
Plantation & $12,313.2$ & $7,866.9$ & -11.39 \\
Irrigation & $3,293.4$ & $2,471.3$ & -2.11 \\
Semi-title land & $1,665.3$ & 394.4 & -3.25 \\
Shrub land & $3,244.6$ & $5,148.8$ & 4.87 \\
Non-vegetation & $1,410.0$ & $3,396.9$ & 5.09 \\
Farm & $10,587.2$ & $9,917.4$ & -1.72 \\
\hline Total & $39,045.0$ & $39,045.0$ & 0 \\
\hline
\end{tabular}

The prediction of land use in 2020 based on the change in forest and housing areas, are shown in the results in Table 2. The results of this simulation show that the change of land use heavily influences the Bekasi River discharge.

Table 2: $\quad$ Discharge of the 25 return periods as results of simulation in 1998, 2003 and prediction in 2020 .

\begin{tabular}{|l|l|l|l|}
\hline & \multicolumn{3}{|c|}{ Q flood $\left(\mathrm{m}^{3} / \mathrm{dt}\right)$} \\
\hline Watershed & 1998 & 2003 & 2020 \\
\hline Cileungsi & 418.6 & 428.4 & 549.1 \\
\hline Cikeas & 182.7 & 194.4 & 212.4 \\
\hline Total watershed & 593.8 & 614.9 & 789.6 \\
\hline
\end{tabular}

\section{The proposed methods to reduce flood risk}

Reducing the flood risk can be done with two methods: increasing the Bekasi River capacity and the reduction of surface run-off with watershed management. The proposed plan to reduce surface run-off is given in two plans as follows. 


\subsection{First plan}

The biggest land use area in the Bekasi watershed is for farms amounting to about 9917.4 ha or $25.4 \%$ in 2003 , so the first plan is treating the farm area using the conservation principle and approaching the farmers about the importance of implementing conservation principles. It is predicted that by 2020 , half $(50 \%)$ of farmers will be willing to treat their land following conservation principles. From simulation results, this plan can reduce surface run-off in 2020 to about 83.5 $\mathrm{m}^{3} / \mathrm{s}$, to be $706.1 \mathrm{~m}^{3} / \mathrm{s}$ (table 3 ).

\subsection{Second plan}

The second plan is to make water retarded structures upstream, which are intended to hold the water upstream to reduce surface run-off. A water retarded structure is planned in the first order with a reservoir volume of $50-300 \mathrm{~m}^{3}$, if it is planned in a farming area each hectare contains two water retarded structures, so that $9917.4 \mathrm{ha} / 2=4,958$ water retarded structure, having a water capacity of $200 \mathrm{~m}^{3}$ From simulation results, this plan can reduce surface run-off in 2020 by about $94.7 \mathrm{~m}^{3} / \mathrm{s}$, to be $694.9 \mathrm{~m}^{3} / \mathrm{s}$ (table 3 ).

Table 3: $\quad$ Comparison of simulated plan results in 2020.

\begin{tabular}{|c|c|c|c|}
\hline Plan & $\begin{array}{c}\text { Q flood } \\
\left(\mathrm{m}^{3} / \mathrm{dt}\right)\end{array}$ & Decrease & $\begin{array}{c}\text { Percentage } \\
(\%)\end{array}$ \\
\hline First & 706.1 & 83.5 & 10.57 \\
\hline Second & 694.9 & 94.7 & 11.99 \\
\hline
\end{tabular}

\section{Conclusion}

Based on simulation results, it is hoped that there is a feasible plan to reduce surface discharge. The implementation of one plan is not enough, so that a combination of plans are needed; if the first plan combined with a second plan will reduce surface discharge by about $176.2 \mathrm{~m}^{3} / \mathrm{s}$, the surface discharge in 2020 will become $613.4 \mathrm{~m}^{3} / \mathrm{s}$.

\section{References}

[1] Fongers D., A Hydrologic Study of the Ryerson Creek Watershed Hydrologic Studies Unit, Land and Water Management, Division Michigan Department of Environmental Quality, Michigan, 2002.

[2] Forest Faculty IPB Jabotabek Digital Conversion, Bogor Agriculture Institute, Indonesia, 2003.

[3] Johnson C., Yung A., Nixon K. \& Legates D., The use of HEC-GeoHMS and HEC-HMS to Perform Grid-Based Hydrology Analysis of a Watershed, Dodson \& Associated, inc., Texas, 2002. 
138 Flood Recovery, Innovation and Response I

[4] Pistocchi A. \& Mazzoli P., Use of HEC-RAS and HEC-HMS model with ArcView for Hydrologic Risk Management, Fortly-Italy, 2001.

[5] Statistic Central Bureau, Environmental statistic of Indonesia, Jakarta Indonesia, 2003. 